\title{
FABRICATION OF TURKIC BÖZ 'FABRIC' IN JAPAN AND KOREA
}

\author{
ALEXANDER VOVIN \\ EHESS/CRLAO, Paris \\ 105 bd Raspail, 75006 Paris, France \\ e-mail: sashavovin@gmail.com
}

This paper represents a long-needed criticism of Miller (2005) which carried over the famous discussion of Turkic böz 'fabric' in the micro-'Altaic' context even further East to Japan and Korea. I demonstrate that Miller's arguments fail on historical linguistics and philological grounds for all five putative 'Altaic' families due in large extent to the faulty nature of either his argumentation or data, or both.

Keywords: 'Altaic', Turkic, Mongolic, Tungusic, Korean, Japanese, böz 'fabric', different fabric names, historical linguistics, philology, comparative method.

To the memory of Roy A. Miller who never felt shy of using a highly polemical language and humour in his numerous publications

Twelve years ago Roy A. Miller (further: RAM) again attempted to divorce Turkic $b \ddot{z} z$ 'fabric' from its likely Mediterranean sources, such as Arabic bazz and/or Greek $\beta v ́ \sigma \sigma o \zeta$ and establish an indigenous 'Altaic' etymology that at the same time accounts for loanwords (Miller 2005). That article contains several outstanding pearls of scholarly wisdom, so I feel compelled to pay obeisance to each of them after providing quotes.

Let us start with CT böz 'fabric, cloth, linen' and Chuv. pir 'id.'. Much ink has been spilled on these two words and their connection to parallels in Mongolic. The history of the debate is intimately connected with the interpretation and subsequent fate of the so-called zetacism: a correspondence of $\mathrm{CT} / \mathrm{z} /$ to Chuv. $/ \mathrm{r} /$ and subsequent interpretations of this correspondence either as $\mathrm{PT}{ }^{*} \mathrm{z}$ (position of critical Altaicists) 
or primary ${ }^{*} r_{2}$ (position of pro-Altaicists). ${ }^{1}$ The details of this debate are well familiar to the readers of this journal, so I will not repeat it here. Instead, I will concentrate on the history of the word in question within the 'Altaic' languages as presented in RAM's everlasting contribution.

"He [Stefan Georg - A.V.] cites only Chuv. pir as the result of the "Bolghars of the Volga" attempting to pronounce their borrowed Arb. bazz; but he neglects to mention that somewhere along the way a considerably more obvious borrowing took place, one that reproduced the Semitic original for this lexical phylum, whatever it may have been, in the far more easily recognized shape of $\mathrm{Chu}[\mathrm{v}$. - A.V.] püs. Both are registered in M. I. Skvorcov, Chuvashsko-russkii slovar' (Moscow, 1982 ${ }^{2}$ ): pir 'linen, flax cloth, unbleached linen, cloth, fabric, textile', p. 296 col. b; püs 'calico', p. 312 col. b. Clearly, both forms are of historical interest; it is also clear that focusing attention solely upon pir and ignoring püs will not do.

On the surface at least, this second Chuvash form (duly noted and documented in Sevortian, op. cit. [(Sevortian 1978, p. 102) ${ }^{3}$ - A.V.] would be an excellent candidate for a virtually unaltered phonetic imitation of whatever may have been the original form(s) behind all these words in all these languages..." "... wherever $\mathrm{Chu[v.} \mathrm{-} \mathrm{A.V.]} \mathrm{püs} \mathrm{came}$ from, and whenever it entered the Chuvash neighborhood of the Turkic linguistic domain, it obviously did not "undergo the sound law $z>r$, wherever and whenever such a sound law was operative - and/or if indeed it ever was, then somehow Chu[v. - A.V.] püs escaped its enforcement." (Miller 2005, pp. 282-283)

Clearly, in RAM's presentation Georg (2003) has no idea either about the Chuvash language or its history, since he failed to account for Chuv. püs. But I am afraid I have very bad news for RAM. First, it is strange that RAM fails to notice that Chuv. püs denotes very specific types of cloth: коленкор, миткаль (Eng. 'calico'), and also бязь (Eng. 'coarse calico'), with the later meaning not mentioned in (Skvorcov 1985, p. 323), but nevertheless present in the language (Andreev-Petrov 1971, p. 67). Second, although the correspondence of $\mathrm{CT} / \ddot{\mathrm{o}} /$ to Chuv. /ü/ does exist, it is helpful to remember that Chuvash vocalism went through very significant changes, and the claim

${ }^{1}$ I agree with the position of Róna-Tas that places more emphasis on the fact that CT preserves the distinction between ${ }^{*} \mathrm{r}$ and ${ }^{*} \mathrm{z}$ while Chuvash mergers this distinction, rather than on the exact phonetic values of PT *r and *z.

${ }^{2}$ Actually, 1985, not 1982.

${ }^{3}$ Incidentally, Sevortian (1978, p. 102) 'duly notes and documents' Chuv. püs as 'Chuvash dialect form', with reference to (Sergeev 1968, p. 53), which is not mentioned by RAM. Sevortian is mistaken, though, as Chuv. püs occurs in Standard Chuvash as well, and Sergeev provides only one dialect attestation for Alsheevo (Sergeev 1968, p. 53) . 
that a vowel is virtually unchanged in only one word makes no sense, because all Chuvash vowels in inherited vocabulary underwent various shifts (Fedotov 1996, pp. 85-118). Moreover, the correspondence of CT /ö/ to Chuv. /ü/ is limited in Chuvash to recent loans from Tatar, such as, e.g.

OT ögüt 'council' Chuv. ükĕt 'id.' < Tat. üget 'id.'

OT törä 'law, custom' Chuv. türe 'id.' < Tat. türä 'id.'

OT böl- 'to divide' Chuv. pül- 'id.' < Tat. bül- 'id.'

In addition, a correspondence of Chuv. /s/ to CT /z/ again does not reveal itself in Chuvash cognates of Common Turkic words. Quite to the contrary, it is unique to loanwords. Thus, out of three phonemes in Chuv. püs, two represent loanword phonology. Third, and most importantly, it helps to know a little the linguistic history of the region. Tatar has two words for '[coarse] calico': bäz and büz (Abdrazakov 1966, pp. 88, 94). Tat. $b \ddot{a} z$ is an apparent loan from Arabic bazz, and it was in its own turn borrowed into Russian as бязь (Vasmer 1950, p. 261). Tat. büz, which is, of course, a direct source of Chuv. püs, itself is a product of a very recent shift of CT /ö/ to Tat. /ü/, which occurred only by the 19th century (Khakimzianov 1987, p. 43). By no means can this shift be older than the 15th century, because in the Kypchak Volga Bulghar monuments, we still see /ö/ and not /ü/, e.g. KVB tört törüt 'four' (cf. Tat. dürt 'id.'), KVB öksüz 'orphan' (cf. Tat. üksez 'id.'), KVB özäk 'kernel, heart' (cf. Tat. üzäk 'centre, kernel, pit'). Thus, Chuv. püs 'calico' < Tat. büz 'calico' < CT böz 'linen, fabric'. Consequently, contrary to RAM, Chuv. püs 'calico' is neither "an excellent candidate for a virtually unaltered phonetic imitation", nor is it a reflex of "original form" in Turkic.

This leaves us with Chuv. pir vs. CT böz 'fabric, linen'. RAM was experiencing a real problem with the vowel in this word, going as far as suggesting that there might be a shift of $* \mathrm{a}>i$ under the influence ... of the following / $\mathrm{r} /$ (Miller 2005, pp. 283-284) - a claim which certainly has nothing to do either with the real world of phonetics or with any real form in Turkic: certainly no form *baz is attested in any Turkic language. ${ }^{4}$ But to get back to Chuv. /i/, RAM forgets to inform his readers that Clauson explained variant forms of CT böz: Turkic bez and Turkm. bizz as due to the late Greek pronunciation of $\beta v ́ \sigma \sigma o \zeta$ as /visso/ (Clauson 1972, p. 389). This traditional explanation may eventually win the day, although it is not without its problems: one has really to explain why Greek/i/ was raised to Turkic/e/. In any case, I do not think that it can be applicable to /i/ in Chuv. pir, simply because Chuv. /i/

${ }^{4}$ The 'reconstruction' of the vowel *a seems to be inspired by MK :pal 'bamboo blind' proposed as a cognate in Starostin - Dybo-Mudrak (2003, p. 329) that RAM simultaneously rejects for semantic reasons but accepts as evidence for reconstructing his *a (Miller 2005, p. 284). This nolose approach that will allow anyone to establish correspondences on the basis of non-cognates and consequently enabling us to reconstruct anything should undoubtedly be hailed as the great methodological contribution by RAM that surpasses anything done in the field of comparative linguistics so far. 
can reflect neither original $\mathrm{PT} * \mathrm{i}$, nor even $\mathrm{PB} * \mathrm{i} .{ }^{5}$ The correspondence of $\mathrm{CT} / \ddot{\mathrm{o}} /$ to Chuv. /i/ appears to be quite regular. Below I use Old Turkic as a representative of Common Turkic:

OT öl- Chuv. vil- 'to die'

OT ört Chuv. virt '[steppe] fire'

OT $̈$ t- $\sim$ Chuv. vit- 'to pass through', etc.

As one can see, the original [+labial] feature of the vowel /ö/ is reflected by the Chuvash prothetic consonant /v-/. Since in CT böz 'fabric' we already have initial /b/ with the feature [+labial] preceding / $\mathrm{i} /$, there is no need for appearance of a prothetic $/ \mathrm{v} /$, which will anyway contradict the rules of Turkic phonotactics with an impossible *bv- cluster. Thus, the change of CT böz $>$ PB *bör $>$ Chuv. pir is absolutely regular, because it is productive-predictive. In any case, it is extremely unlikely, even impossible that Chuvash would preserve PT $*$ i intact. ${ }^{6}$

The next step is to pay obeisance to RAM's expertise in Mongolic historical linguistics. Let me start with another quote:

"It [Chuv. püs - A.V.] also would represent a virtually accurate phonetic imitation of any of a number of Mongol forms originating, without question, in the same Wanderwort source (cf. MM böz, WM bös, Ord. Kalm. bös, Mongr. bos, etc. 'cotton textile', N.N. Poppe, Introduction To Mongolian Comparative Studies [Helsinki, 1955], pp. 49, 122). We ought never to forget that what we are accustomed to call loanwords are, in historical fact, no more than the results of imitation of one language by speakers of another, and so the degree of phonetic success, or failure, in such imitations is relevant to their historical study. Equally clear is the fact that summarily to account for Chuv. püs by labeling it a "loan from Mongol" would accomplish very little..." (Miller 2005, p. 283)

The reader is probably as astonished as I was with this passage of unique insight into historical linguistics and loanword theory: I am not sure one can understand it even after reading several times. In short, is Chuv. püs a loan from Mongolic, or is it not? Are the words borrowed from one language to another or are they always just imitated? Who are those linguists who claim that Chuv. püs is a loan from Mongolic? Unfortunately, RAM apparently fights here with windmills: no linguist even with average knowledge of Turkic and Mongolic as well as of their histories who can do scholarly work beyond just uncritically picking Chuv. püs from a Chuvash-Russian bilingual dictionary will immediately see that Chuvash püs is a late loan from Tatar as demonstrated above.

${ }^{5}$ Fedotov (1996, p. 109) provides six examples of cases when Chuv. /i/ seems to correspond to OT /i/. It is necessary to note that two of these examples reflect PT *ï: OT bij bï ' 1000 ' Chuv. pin 'id.', OT biš $\sim$ bǐs 'to ripen' $\sim$ Chuv. piç 'id.' and two reflect Turkic *è: OT tik- $\sim$ tek- 'to stick in' $\sim$ Chuv. čik- 'id.', OT iki $\sim \dot{e} k i$ '2' $\sim$ Chuv. ikkĕ 'id.'. The remaining two examples are certainly not sufficient to justify this 'correspondence'.

${ }^{6}$ For other possible reflexes of PT $* i$ in Chuvash see (Fedotov 1996, pp. 108-110). 
Incidentally, citation from Poppe that RAM provides for his readers with the above is carefully 'edited', so I provide the full citation below: ${ }^{7}$

"WM bös 'cotton textile', MM (Mu[qaddimat 'al-'Adab - A.V.].) böz< Turkic, Dag. buun̂ 'textile', Mang. bos 'cotton textile', Ord. bös, Kal. bøs, Bargu Buriat bød, Alar Buriat bød, Kalm. bös 'id.'” (Poppe 1955, p. 122)

Therefore, we learn two important things mentioned by Poppe, but omitted by RAM: first, that at least Western MM (and not just Middle Mongolian in general as maintained by RAM) borrowed its form $b \ddot{o z}$ from Turkic; and, second that this form is attested in the Muqaddimat al-Adab. However, WMM böz is not the only form found in Middle Mongolian. In order to trace the history of this word in Mongolic we have to take into account all Middle Mongolian attestations. Poppe can be partially excused for not doing so, because at the moment of writing his 1955 book not all relevant primary sources had been published. But RAM of course could have consulted all these sources, published long before 2005, but apparently diving into various scripts in which MM was written as well into other primary sources including Korean and Japanese, too (as we will see below more than on one occasion) caused our respected guru too much stress.

The word in question is attested in Middle Mongolian in four different texts. Interestingly enough, contrary to Poppe's statement above, it appears by itself in the Muqaddimat al-Adab, and WMM böz is found there only in the following expressions: bözčī-n ger بوزجين كير 'weaver's house' and böz-în arqaq بوزين ارقاق 'loom' (MU 124), ${ }^{8}$ both apparent loans and/or calques from Turkic, cf. Chag. bözči-ning ewi 'weaver's house' and böz arqayï 'loom'. WMM böz 'linen' appears by itself only in LD (1266). ${ }^{9}$ In his commentary to this entry in LD, Poppe tells us quite straightforwardly that WMM $b \ddot{o z}$ as well as Mongolish bös (presumably Poppe means

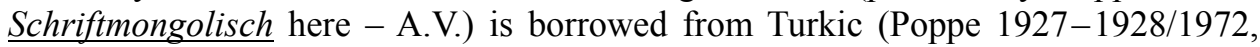
p. 1266). However, this remark of Poppe safely escaped RAM's attention. But even if RAM has never consulted LD, or consulted and missed Poppe's comment there, it is completely incomprehensible how he manages to miss a simple linguistic (not even a philological!) fact that WMM $b \ddot{z} z$, written as بوز or Arabic script with letter j $\{z\}$, can only be a loan in Middle Mongolian, a language which has no /z/ in its phonemic inventory (Rybatzki 2003, p. 64). Therefore, the graphic form böz with $-z$ tells us that this is a graphic loanword, and that phonetically the word was likely [bös]. This is furthermore supported by the attestations in Eastern Middle Mongolian. Thus, we find EMM bös 'cotton cloth' written as 博絲 (EM paw'szp) in (HYYY 12b.1) and in (KMQB II: 16b.4). ${ }^{10}$ These clearly have a /s/ and not /z/, and on the basis of

${ }^{7}$ As in the case with RAM, I replace Poppe's abbreviations for languages with my own.
${ }^{8}$ Cited according to Poppe's edition (Poppe 1938).
${ }^{9}$ Cited according to Poppe's edition (Poppe 1927-1928/1972).
${ }^{10}$ Publications of Eastern Middle Mongolian data are easily available: Lewicki (1949, 1959), ${ }^{10}$ Publications of Eastern Middle Mongolian data are easily available: Lewicki (1949, 1959),
Haenisch (1952), Haenisch (1957), Ligeti (1972a, 1972b), Mostaert (1977, 1995), Kuribayashi (2003). 
the combined evidence from Western and Eastern Middle Mongolian data, we can safely establish MM bös, which certainly can only be a loan from CT $b \ddot{z} z$.

Last, but not least we have one more word attested in Middle Mongolian that has a paramount importance for the whole discussion above. Here enters WMM bör 'coarse calico' (бязь) attested in a WMM compound bör kesek 'a piece of coarse calico', translated by Chag. parča kesek 'id.' (MU 217). It is quite clear that the WMM compound itself, as well as its components are Turkic loans, but in this case we have WMM bör with $-r$, and not $b \ddot{z} z$ with $-z$. The only realistic answer to this problem is that while WMM böz is a loan from CT-type language, WMM bör is a loan from a Bulghar-type Turkic language. Now we can recollect that a tentative PB *bör was suggested above as a source of Chuv. pir. WMM bör represents an actually attested reflex of this proto-Bulghar form, although only in the form of a loanword that survived in Middle Mongolian. With this last piece of evidence, I think the issue should be finally cleared, and I should say that much to chagrin of RAM, yes, we indeed have the shift of $z>r$ in Turkic philologically documented as demonstrated above.

Now it is time to turn our attention towards Tungusic data, or more exactly to RAM's problem with these data:

"This is particularly the case with an impressive set of Manchu-Tungus forms that, by reason of their shapes and meanings, must obviously be studied in conjunction with the Turkic and Mongol item(s) at issue, viz., Ma., Neg., Nan. boso busu, Sol. basu, Or., Uil.. busu 'fabric' (TMS I, 78 [(Cincius 1975, p. 78) - A.V.], Sevortian op. cit., [1978 - A.V.] p. 104). Most curiously, we find no treatment of, or even speculation upon, any of these forms, Manchu-Tungus, Turkic, and Mongol alike, in the secondary sources where we might reasonably expect to encounter them, i.e., neither in G. J. Ramstedt's Studies in Korean Etymology (Helsinki, 1949), nor in his Einführung in die altaische Sprachwissenschaft (Helsinki, 1957, 1952 [sic]). It is impossible even to speculate why the great Finnish pioneer of Altaic historical linguistics remained silent upon the connection(s) that he must have observed among all these forms; even the late Songmoo Kho's exhumation of Ramstedt's unpublished notes (Paralipomena of Korean Etymologies, Helsinki, 1982) throws no light upon this question." (Miller 2005, p. 280)

I trust I can help to solve this puzzle very easily. As the reader will see shortly, this is no puzzle at all - in all probability only RAM had problem with Ramstedt's lack of comment on the Tungusic forms quoted above.

We have to start with the review of the data themselves, because as we already know, RAM has problems with their accurate presentation. The magnitude of the data corruption caused by RAM is better presented in a tabular form: 
Table 1. Tungusic data from Cincius (1975) vs. Miller (2005)

\begin{tabular}{|l|l|l|}
\hline Language & Data in (Cincius 1975, p. 78) & RAM's presentation \\
\hline Solon & ${\text { baš' }{ }^{11}}^{11}$ & basu \\
\hline Neghidal & boso $\sim$ bosụ & boso $\sim$ busu \\
\hline Oroch & busu, busuyu & busu \\
\hline Ulcha & bụsụ & busu \\
\hline Uilta & bụsụ & busu \\
\hline Nanai & boso & boso $\sim$ busu \\
\hline Manchu & boso & boso $\sim$ busu \\
\hline
\end{tabular}

Thus, RAM invented non-existing forms *busu for Neghidal, Nanai, and Manchu, ignored the fact that Ulcha and Uilta forms have /u/, not /u/, misquoted Solon form as basu, and cited only one out of two available Oroch forms. This is an accuracy of approximately $30 \%$, a magnificent start for any historical linguistic exploration. I also have to add that all Tungusic words basically mean 'cotton cloth', not just any kind of 'fabric'.

A brief look at the correct set on the left will tell anyone familiar with the basics of Tungusic historical phonology that all these forms are not Tungusic cognates, since there are no regular correspondences between them, and, therefore, no reconstruction of a proto-Tungusic archetype is possible. Namely, a correspondence of Neg. /o/ to Nan. /o/ implies a reconstruction of a PTu *u, which should be reflected in Manchu as $/ \mathrm{u} /$, not as $/ \mathrm{o} /$. The same correspondence requires Ul. and Uil. back vowel /u/, not central vowel /ụ/ (Cincius 1949, pp. 83-89). In addition, final $-u$ in Nan. bosu cannot be satisfactorily explained either, because it violates the vowel harmony in Nanai. The lack of any attestations in Northern Tungusic languages, with the exception of the mysterious Solon baš'u is quite revealing: it demonstrates that we are not dealing here with a proto-Tungusic item. In order to finish once and for all this nonsensical point view that regards all these words as reflexes of proto-Tungusic, one should trace the possible origin of these Tungusic words for 'cotton cloth', because they surely were borrowed from more than one source.

I agree with both Rozycki (1994, pp. 35-36) and Doerfer (1985, p. 115) that Ma. boso is a late loan from Mongolian. As expected, RAM is again having hard time "with an undocumented claim that phonological evidence shows the Mongol $>$ Manchu borrowing to have been "late"" (Miller 2005, p. 280). I will gladly provide some help. Let us first review philological evidence. In Jurchen, at the first glance there are two competing forms: Jur. busu (充禾) transcribed as 卜素 $\left(\mathrm{EM}^{12} p \check{u} s u\right.$ ) in the

\footnotetext{
${ }^{11}$ Attested only in Ivanovskii's (1894, p. 23) materials, therefore, given the strange vocalism of the first syllable, this form is suspicious.

${ }^{12}$ Early Mandarin reconstructions are cited according to Pulleyblank (1991).
} 
Sino-Jurchen Vocabulary of Interpreters, ${ }^{13}$ and Jur. bosu transcribed as 博素 (EM $\mathrm{paw}^{\prime} \mathrm{su}^{\prime}$ ) in the Sino-Jurchen Vocabulary of Translators (Kane 1989, p. 332). Incidentally, inscriptional evidence supports the first form: in the inscription of Yongningsi (永寧寺) temple we find Jur. buči or busï (充乐) ${ }^{14}$ “cotton cloth' (Yong 7). The last form demonstrates that Jur. /u/ in busu is a central / $\mathrm{u} /$ rather than a back /u/. Then, of course, Jur. bust or busï will be an older loan from Mongolian bös either prior to the Great Mongolian Vowel Shift or in the very beginning of it, when Mongolian $/ \ddot{\mathrm{o}} />/ \mathrm{u} /$ first. Jur. bosu and Ma. boso reflect loans after the Great Mongolian Vowel Shift, when Mongolian /ö/ shifted to the back centralised vowel / $₫ /$, which is found today in Khalkha and many other Mongolic dialects. It is also worth noting that, to the best of my knowledge, Ma. boso occurs for the first time only in the late 17th-early 18th century:

boso-be ali-me gai-xa manggi

cloth-ACC take-GER take-PERF after

after [Bujantai] took the cloth (YK III: 214) ${ }^{15}$

Ma. boso is also conspicuously absent from Old Manchu; thus, e.g., it is not attested in TFAXB. Thus, all the facts, both linguistic and philological, support Doerfer's and Rozycki's position that Ma. boso is a late loan from Mongolic and contradict RAM's unfounded objection to it. If RAM wants to demonstrate that Ma. boso is either old Mongolic loan, or that it represents a 'cognate' of MM bös going back to 'protoAltaic', he should have provided some evidence for his point of view, rather than accuse his opponents in producing undocumented claims.

We should now get back to the rest of Tungusic forms that were saved above from their vivisection by RAM. Now that we know the relative chronology of Jurchen and Manchu forms, the remaining task is relatively easy. Neghidal boso should be borrowed from Ma. boso, while Neghidal bosu is a loan from Jur. bosu. Nanai boso is certainly a direct loan from Ma. boso. The remaining forms: Or. busu and Ul., Uil. busu should all be loans from Jur. busu.

Therefore, given all these facts, we should conclude that all Tungusic forms are either loanwords from different Mongolic sources or intra-Tungusic loans. This multilayered origin certainly successfully explains irregularities in their vocalism outlined above.

This, therefore, explains why Ramstedt never involved any of these Tungusic forms into his Altaistic comparisons. Although, in my opinion, the great Finnish scholar was misled about the true relationship among 'Altaic' languages, he knew those languages well, as well as their historical phonology, and he was a serious scholar and not a dilettante who would deny existence of any loanwords among the 'Altaic' languages, or just to pay a lip-service to the existence of these loanwords in principle at

\footnotetext{
${ }^{13}$ Kiyose (1977, p. 128) reads bosu, but this cannot be correct, because the Chinese character $卜$ never had the reading $/ \mathrm{po} /$.

${ }^{14}$ The last character 乐/či/ is probably a mistake for 舟/sï/ (Jin 1984, pp. 55, 166). Kiyose (1977, p. 81) reads 我 as /ji/.

${ }^{15}$ Pagination is given according to Imanishi (1992) edition.
} 
the same time portraying them as 'cognates'. Clearly, for him these Tungusic forms were Mongolic loans, therefore, he chose not to include them into his studies. Anyway, I hope the RAM's puzzle is now solved for the reader, and we can move on further to the East. As usual, I begin with a quote:

"The Japanese evidence for the survival of this term in Old Japanese pusuma 'a kind of bedding, a coverlet', though ignored in EDAL [(Starostin et al. 2003) - A.V.] has long been available in Chapter 5, "Linguistic Evidence and Japanese Prehistory", in: R. J. Pearson, ed., Windows on Japanese Past: Studies in Archeology \& Prehistory (Ann Arbor, 1986), pp. 101-120 [(Miller 1986) - A.V.]. In addition to complete citations of the linguistic evidence, both Japanese proper and comparative Altaic, the treatment there documents the intricate manner in which this term related to a royal-descent myth, known in both Korean and Japanese versions, in which the gods come down from heaven wrapped in some sort of cloth. It also explored the Altaic, and especially the Tungus-Man$\mathrm{chu}$, linguistic connections of OJ pusuma, a secondary compound whose suffix *-ma forms denominal nouns for objects made from a given substance (cf. Nanai boso 'cloth', bosoma 'made of cloth')." (Miller 2005, p. 284)

To set the record straight from the beginning, Miller (1986, pp. 113-114) dedicates slightly more than half a page to OJ pusuma and its alleged 'Altaic cognates', which were already dealt with above. In this article RAM presents neither 'complete citations of the linguistic evidence', nor any other 'treatment that documents' any relevant information to the internal history of OJ pusuma 'bedding, quilt, comforter'. However, RAM makes there a statement that repeats the same methodological fallacy that was cited above, but in a much more direct form:

"...we see that that OJ pusuma is a secondary compound, incorporating the well-attested Tungusic suffix *-ma (Benzing 1955, p. 1039, §1052; Dmitrieva 1979, p. 163) that forms denominal nouns expressing the idea that some object is made from a given substance..." (Miller 1986, p. 113)

We have here a true revelation that would be destined to influence the fate of historical-comparative linguistics if it were noticed and adopted. Fortunately for the field, it was not. RAM reveals to us above that one can find Tungusic suffixes in Old Japanese if, of course, one tries very hard. Before RAM 1986 article historical linguists used to believe that Japanese has Japanese suffixes, and Tungusic has Tungusic suffixes, unless, of course, these suffixes could be demonstrated to be loans. Some of us, including the author of these lines, still cling to an extremely outdated belief that any segmentation in a given language can be done only on the basis of the internal data of this language. It is, therefore, extremely hazardous to segment OJ pusuma into *pusu-ma just because Tungusic happens to have the suffix - $m a$. This fallacy becomes aggravated even further, because so far nobody managed to demonstrate that Old Japanese and Tungusic are genetically related. Certainly, there is no suffix -ma that forms "denominal nouns 
expressing the idea that some object is made from a given substance" either in Old Japanese or in any other variety of Japonic. Thus, there is zero internal Japonic evidence that OJ pusuma 'bedding' can be segmented as *pusu-ma.

Another spectacular achievement of RAM is his outstanding discovery of Tungusic suffix *-ma that forms "denominal nouns expressing the idea that some object is made from a given substance". The problem here is that such a suffix simply does not exist. There is Tungusic $-m a /-m e$ that forms denominal relative adjectives like Nan. seleme 'made of iron', bosoma 'made of cotton cloth', etc. ${ }^{16}$ It is necessary to note that Benzing properly calls these formations 'Denominale Adjektive' (Benzing 1955, pp. $1038-1039, \S 105 \mathrm{~d}$ ), in the same passage that according to RAM allegedly discusses denominal nouns. RAM's reference to Dmitrieva $(1979$, p. 163) as discussing Tungusic denominal nouns in -ma is simply anecdotal, as Dmitrieva discusses there Turkic deverbal nouns. Apparently RAM had hard time differentiating between Tungusic and Turkic data on the one hand, and between denominal and deverbal formations on the other. We should not forget either that all Tungusic cotton cloth words are ultimately loanwords from Mongolic, either directly, or via other Tungusic intermediaries. Adding to them the suffix - $m a$ does not eradicate their loanword status in Tungusic. Finally, comparing OJ pusuma 'bedding' that is a noun with Tungusic relative adjectives makes little sense from the functional point of view.

Martin (1987, p. 419) suggested a tentative etymology of OJ pusuma as ? $<$ *pu(-)s[a-]u B mo 1.3b 'garment to lie down in'. I am skeptical of this etymology as well, although it is of course superior to RAM's attempt to find a non-existing Tungusic suffix in Japanese. One of the reasons of this skepticism is that WOJ mö means 'skirt ${ }^{17}$ rather than 'garment' in general (JDB p. 737). Second, WOJ $m \ddot{o}$ 'skirt' presented as $m o$ in JDB (p. 737) should really be $m \ddot{o},{ }^{18}$ as it is attested as such in book five of the Man'yōshü, which shows high percent in accuracy in $m \hat{o}$ vs. $m \ddot{o}$ spellings (Bentley 1997), contrary to the traditional point of view. The relevant example:

\section{久礼奈為能母能須蘇奴例弓 \\ kurenawi n-ö mö̈nö susô nure-te \\ crimson red DV-ATTR skirt-GEN hem wet(INF)-SUB \\ [girls], wetting hems of [their] crimson red skirts (MYS V: 861)}

Therefore, the WOJ word for 'skirt' is $m \ddot{o}$ and not $m \hat{o}$, and this makes the alternation $m \ddot{o} \sim m a$ rather dubious. In addition, existence of the allomorph $-m a$ of $m \ddot{o}$ in strong labial environment in * pusu-ma is very unlikely. ${ }^{19}$

${ }^{16}$ See Boldyrev (1987, pp. 78-79) for numerous examples of denominal relative adjectives in $-m a /-m e /-m o$ from various Tungusic languages.

${ }^{17}$ One, of course, should remember that skirts in Ancient Japan were pretty much alike to skirts worn nowadays in Thailand and other parts of South-East Asia, which represent a piece of cloth wrapped around hips and legs, and did not resemble modern European skirts.

${ }_{18}^{18}$ In a different place Martin (1987, p. 484) also reconstructs *mö.

${ }^{19}$ There is, of course, WOJ pakama LLL 'hakama' that according to Martin may invite segmentation *paka-ma < *paka-mo 1.3b 'man's skirt', but as Martin notes himself this etymology is incongruent with high register of OJ pak- A 'to wear' (Martin 1987, p. 396). I should also add that if one wants to see *-ma 'skirt' in both tentative *pusu-ma and *paka-ma, one has to deal with differ- 
Furthermore, it is quite clear from the oldest Western Old Japanese attestation of pusuma that it has nothing to do with 'skirt'. This attestation is very important for the further discussion, therefore, I provide the citation below:

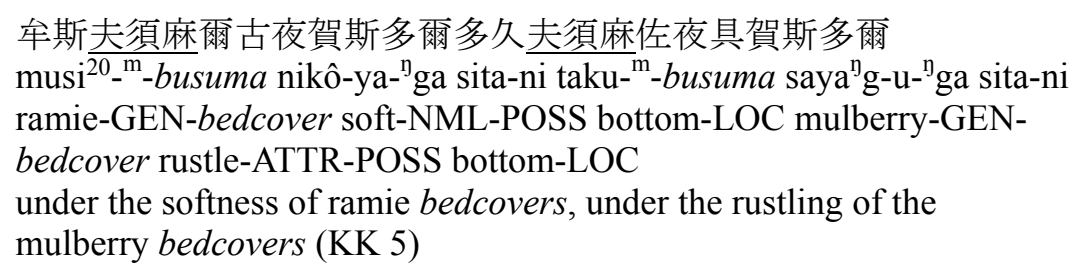

On the basis of this example, it is possible to make one more argument against RAM's extravagant connection of this word with Mongolic loanwords in Tungusic, although it is of lesser importance than the previous arguments: OJ pusuma was made out of fibers of ramie or mulberry tree bark. In addition, it appears that it could also be made out of hemp, the latter practice being textually confirmed for both Western and Eastern Japan. The first example below is from a text in Western Old Japanese, and the second one is from a text in Eastern Old Japanese:

寒之安礼婆麻被引可賀布利
SAMU-KU ${ }^{21}$ si ar-e- ${ }^{\mathrm{m}}$ ba $A S A-^{m}-$-BUSUMA PÎK-Î-ka ${ }^{\mathrm{m}}$ bur-i
cold-INF exist-EV-CON hemp-GEN-bedcover pull-INF-cover.head-INF
when it is cold, [I] pull over my head the hemp bedcover (MYS V: 892)
安佐提古夫須麻許余比太爾都麻余之許西祢
asa-te kô- $^{\mathrm{m}}$-busuma kö yöpîn ${ }^{\mathrm{n}}$ dani tuma yös-i-köse-n-e
hemp-cloth DIM-DV(ATTR)-bedding this night PT spouse bring close-
INF-DES2-DES-IMP
Oh, hemp cloth bedding! [I] wish [you] would bring my spouse just
tonight (MYS XIV: 3454 )

Thus, Old Japanese bedcovers could be made from a cloth made of mulberry bark fibers, ramie fibers, and hemp. It is conspicuous that 'cotton' that underlies all Tungusic and Mongolic words discussed above is not even present. Therefore, given all prob-

ent morphological forms of the preceding parts if they are perceived as OJ pus- 'to lie down' and pak- 'to wear'. Thus, this etymology is better to be abandoned.

${ }^{20}$ Japanese tradition takes the word musi here as 'insect', commenting that it implies a silkworm that produces silk, which is, of course, soft (Tsuchihashi 1957, p. 41; Ogihara-Kônosu 1973, pp. 105-106; Tsuchihashi-Kônosu 1972, p. 50), or as 'warm' (Aiso 1962, p. 34), although Ogihara-Kônosu (1973, pp. 105-106) and Tsuchihashi-Kônosu (1972, p. 50) also acknowledge the possibility that this may be musi 'ramie'. Parallelism between taku 'mulberry' and musi 'ramie' in this poem is in favour of the latter interpretation. I believe that WOJ musi 'ramie' must be a loan from $\mathrm{OK} *$ mosi (> MK mwosi LL) 'ramie' that predates raising of $\mathrm{PJ} *_{\mathrm{o}}$ to WOJ /u/. RAM is aware neither of the existence of WOJ musi 'ramie', nor of the controversy surrounding the interpretation of KK 5 in Japanese tradition, as he puts it flatly that WOJ musi 'ramie' is not attested "for the Old Japanese period" (Miller 1989, p. 109).

${ }^{21}$ Transliteration of semantographic parts of the OJ and OK scripts is rendered by capital letters. 
lems listed above, it is necessary to divorce OJ pusuma 'bedcover' from its 'Altaic' look-alikes.

Another OJ word that RAM tries to connect to Chuv. pir 'linen, cotton cloth' is $\mathrm{WOJ}^{22}$ pire 'long scarf worn by women put over neck and hanging down from both shoulders'. I have already pointed out above that /i/ in Chuv. pir is a result of quite recent development that postdates WOJ pîre by several centuries. This fact alone could rule out this fantastic etymology from the start, but for the argument's sake I will deal with WOJ pire 'long scarf' on its own terms.

The first fact that attracts our attention is that the absolute majority of WOJ and $\mathrm{MJ}$ nominals ending in -re are either extended stems of pronouns in -re (like wa $\sim$ wa-re 'I') or deverbal nominal forms derived from vowel verbs with stem ending in - e (traditional shimo nidan class). Non-derived nominals in -re are extremely rare: WOJ are 'village, settlement' (not attested phonetically and known only from later kana glosses), WOJ kure 'crude log', MJ kure 'lump', WOJ si gure 'drizzling rain', OJ ure 'end', WOJ arare 'hail', WOJ sumîre 'violet', WOJ mare 'rare', WOJ pîre 'long scarf', and MJ pire 'fin'. This anomaly certainly has to be explained.

Martin considers WOJ pire 'long scarf' and MJ pire 'fin' to be related words ${ }^{23}$ (they belong to the same accent class $2.1 \mathrm{HH}$ ) and derives them both from adjectival nominal *pira 'flat' + nominaliser $-i^{24}$ (Martin 1987, p. 408). As far as 'fin' is concerned, this derivation seems plausible both semantically and morphologically, as a couple of nominals in -re listed above seem to be derived in a similar manner: WOJ kure LL (2.3) 'crude log' can be derived from kura- HH (A) 'dark', since a crude log covered with bark is certainly darker than a polished one. However, the incongruence of initial register may speak against this etymology. The derivation of WOJ mare 'rare' from *maray is quite certain, though, cf. WOJ mara-pîtö 'guest', lit. 'rare person'. I am a little more doubtful about the derivation of pîre 'long scarf' from *pira'flat' - surely all pieces of cloth are flat by definition, but why the name of a ceremonially important object that was supposed to have magic powers (JDB 627) would be derived from a word 'flat'?

We lack the information about the material that pire was made of during Nara (710-794 AD) and Asuka (592-710 AD) periods, but fortunately we know that during Heian period (794-1192 AD) it was made either of silk gauze or twill (Murofushi 1979, p. 78). This casts further doubt on RAM's alleged connection with Chuv. pir 'cotton cloth, linen', because although silk as material may suggest a continental origin of WOJ pire, it makes Inner Asian connection quite unlikely.

The attestation of pire in Japonic is limited to Western Old Japanese and to Middle Japanese. It is not present either in Ryukyuan or even in Eastern Old Japanese. This limited distribution strongly suggests that the word in question is either an innovation or a loanword in Central Japanese. I have already dealt with a possibility of an innovation above. Let us now consider that pire can be a loanword.

${ }^{22}$ The word is not attested in Eastern Old Japanese.

${ }^{23}$ The same position is taken by Ōno-Satake-Maeda (1990, p. 1144).

${ }^{24}$ Martin (1987, p. 408) writes - $C i$, , but in my opinion there is little if any external Japonic evidence for reconstructing any consonant here. 
In addition to the list of nouns in -re presented above two apparent loanwords from Old Korean ending in -re can be added: WOJ mure 'mountain' < Paekche mure (ムレ) (NS IX: p. 262), (NS XIX: p. 92), mura, mora (ムラ、モラ) ‘mountain’ (NS $\mathrm{XV}$ : p. 412), cf. MK .mwo lwo (YP IV: p. 21b), :mwoy 'mountain'; and WOJ kure 'Wu region of China', with an original meaning referring to Koguryǒ rather than to Wu (Mabuchi 2000, pp. 421-430). Among Paekche words recorded in the Nihonsho$k i$, we also have Paekche nare (ナレ) (NS XVII: p. 28), (那禮) (NS IX: p. 247) 'stream', also ending in -re. The resemblance of WOJ pire to these Old Korean words in -re may, of course, be purely coincidental, and it alone cannot prove that WOJ pire is a loanword from Old Korean. Unfortunately, the word is not attested among meager Old Korean texts that managed to survive. However, we have important textual evidence that the 'magic long scarf' was brought from Old Korean kingdom of Silla to Japan:

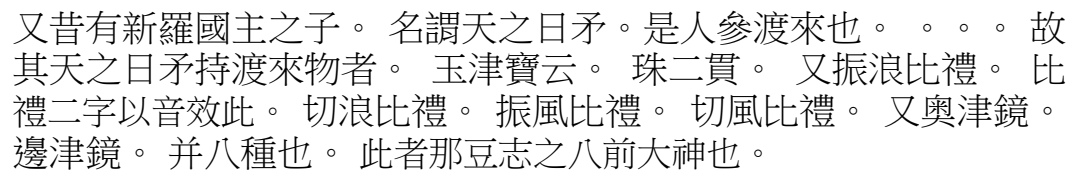

Moreover, in the old times there was a son of a ruler of the land of Silla, who was called Amë-nö pî-pokö [lit. Sun-spear of Heaven - A.V.]. This person crossed over to [Japan]. ${ }^{25}$... So the things that Amë-nö pî-pokö brought here, and which were called the treasures of jewels, were: two strings of pearls, a wave-raising long scarf [two characters 比禮 /pîre/ are to be read by their sound], a wave-calming long scarf, a wind-raising long scarf, a wind-calming long scarf, also a mirror of the offing, and a mirror of the shore. [These are Eight Great Deities of Intusi.] (KJK II: 66a, $67 b-68 a)$

The passage above, apparently unnoticed by RAM, who normally works only with secondary sources, ${ }^{26}$ is written almost completely in Classical Chinese, but it also includes some non-Chinese elements that further support the Korean provenance of the WOJ pire 'long scarf'. The first of this elements is WOJ genitive-locative case marker $-t u$ that represents a loan from OK genitive marker 吨 - $c \ddot{i}$ (Vovin 2005, pp. 152-158). It is written as 津, and occurs in the phrases 玉津寶 'treasures of jewels', 奥津鏡 'mirror of the offing', and 邊津鏡 'mirror of the shore'. The second is the character 那 that is glossed by katakana イ / $\mathrm{i} /$ in the variant spelling 那豆志 of the placename 伊豆志 /INtusi/ (Takagi-Toyama 1958, p. 261), ${ }^{27}$ but should have been

${ }^{25}$ I omit a long story explaining the reason why Amë-nö pî-pokö happened to come to Japan, because it has no relevance to the present discussion.

26 "Miller's theories on Japanese and 'the other' Altaic languages, which are founded only upon secondary sources, also repeatedly disclose misconceptions concerning theories proposed by other scholars" (Kiyose 1991, p. 234).

${ }^{27}$ Other modern editions of the Kojiki automatically replace this variant 那豆志 with the more frequent variant 伊豆志, because the latter occurs in the next line of the manuscript and elsewhere (Kurano 1958, p. 256; Ogihara-Kônosu 1973, p. 265; Saeki-Kobayashi 1982, p. 222). 
read as /na/, if it were just a regular man'yōgana sign. The only tangible explanation for reading /i/ of the character 那 would be the assumption that this /i/ represents a kungana reading. But while the kungana reading /i/ of the character 那 meaning 'that' in colloquial Middle Chinese has no basis in Western Old Japanese, OK *i 'this' (MK ' $i$ 'id.') seems to be a likely candidate. Thus, not only did we learn from the story above that pire 'long scarf' was brought from Korea to Japan, the text of the story also has elements of Korean origin. Therefore, although we have no actual attestation of the ultimate Korean source of WOJ pire, there is no doubt that the word originated on the Korean peninsula.

Now that both OJ pusuma 'bedcover' and WOJ pire 'long scarf' are saved from their extravagant but fallacious connections with Chuv. püs 'calico' and Chuv. pir 'cotton cloth, linen', we can proceed to the rescue of the Korean word for 'cloth'. RAM cites MK pwòy (sic! - A.V.) 'hemp cloth', "attested as early as a Buddhist text of 1449", noting that "the modern vocalization as pey is first attested in a text of 1736" (Miller 2005, p. 284). To this he further adds LOK attestation in (KY \#218, \#220), ${ }^{28}$ transcribed by the Chinese character 背 'back', which RAM reads as pwoy (Miller 2005, p. 285).

RAM starts dealing with Korean data with a sloppy citation: MK pwóy actually has HIGH pitch, and not LOW as presented by RAM. This is properly reflected not only in the Buddhist text of 1449, namely Sekpo sangcel, where the word is written as pwóy (Sek XIII: 52a) with HIGH pitch, (not pwoy with LOW as RAM would like to have it), but also in all secondary sources. Thus, HIGH pitch of MK pwóy is also promptly indicated in all three easily accessible dictionaries of Middle Korean: Yi co e sacen (LCT 392), Yeys mal-kwa kul (Hankul hakhoy 1999, p. 5113), and Kyohak koe sacen (Nam 1997, p. 698), the latter being the only one that RAM managed to consult, but apparently did not trust and therefore managed to misspell the first part of its title as [Kyoha] (Miller 2005, p. 285). As the reader will see below, the fact that the word in question has HIGH, and not LOW pitch has a devastating impact on RAM's 'Altaic' etymology.

The second problem may be not so apparent at the first glance. It concerns the original nature of the vocalic nucleus in EMdK pey vs. MK pwóy: RAM believes that the vowel -wo- [o] in MK pwóy is original, while -ey- [e] in EMdK pey is secondary. This is where the trouble starts. First, typologically an assimilation of *pe $>/ \mathrm{po} /$ after a labial $/ \mathrm{p} /$ is usual, but the reverse dissimilation of $*$ po $>/ \mathrm{pe} /$ is rather unusual. Typology alone, of course, cannot prove anything. But there are other problems. Like RAM, the majority of scholars read LOK word for 'cloth' transcribed by the Chinese character 背 (KY \#218) as *pwoy, equating it with MK pwóy, e.g. (Kang 1980, p. 84). This reading is certainly influenced not only by MK form, but also by LMC reconstruction *puaj' of the character 背 (Kang 1980, p. 170; Pulleyblank 1991, p. 31). Nevertheless, it is necessary to keep in mind that although the transcriptional system employed in the Kyeylim yusa in 1103 AD preserves some elements from the Late Middle

\footnotetext{
${ }^{28}$ I use numbers of entries according to Kang's (1980) edition, RAM follows the numbers according to (Sasse 1976).
} 
Chinese of the 8th-9th centuries, temporarily it is much closer to Early Mandarin. Pulleyblank (1991, p. 31) reconstructs EM *puj’ for 背. Again, the first superficial impression may be that this reconstruction supports RAM's reading, but we should keep in mind that Chinese transcription is not an IPA which allows any possible combinations. Chinese syllabary at any period of the Chinese language history had certain gaps in the distribution and combination of phonemes within its syllables. Thus, while Early Mandarin has syllables /paj/,/pje/, /puj/, or /pən/, in Pulleyblank's reconstruction, it has no syllable *poj. Therefore, Sun Mu, the author of the Kyeylim yusa, simply might have no choice when transcribing an LOK syllable like *pəj or ${ }^{*} \mathrm{p} \wedge \mathrm{j}$. In addition, there is some evidence demonstrating that Pulleyblank's reconstruction for 背 as * puj may be incorrect:

(1) Pulleyblank (1991, p. 31) reconstructs both 背 'back' and 備 'to prepare' as EM *puj'. In Sino-Mongolian system of writing employed in MNT, 備 indeed is used for the phonetic sequence /bui/ (Hattori 1946, p. 118; Lewicki 1949, p. 32; Haenisch 1962, p. 185). The character 背 'back' is not used, but its Early Mandarin near-homophone 北 'north' also reconstructed by Pulleyblank (1991, p. 31) as EM *puj ${ }^{29}$ is used for phonetic sequences /bei/ or /be/ (Hattori 1946, p. 118; Lewicki 1949, p. 47; Haenisch 1962, p. 185). ${ }^{30}$ This discrepancy in usage in MNT suggests that 背 'back' and 備 'to prepare' had different pronunciations in Early Mandarin.

(2) Chinese transcription of Jurchen, which is also based on Early Mandarin, used 背 to transcribe phonetic sequences /bei/ or /ba/ (Jin-Jin 1980, p. 112). Thus, combined Middle Mongolian and Jurchen transcriptional evidence indicates that 背 'back' had EM reading *pəj', identical to Modern Mandarin $b e i^{4}$ [pəj'].

(3) There is LOK word titpəy 'purple', transcribed in Chinese characters as 質背 (KY \#242) where the character 背 is also used. It has only partially survived into MK as cotit 'id.' (HMCH II: 30a), but it is fortunately preserved as OK 紫布 TITp $\partial$ (SHK II: 1) in a partially phonetic spelling, where the native Korean reading of the character 布 'cloth' is used phonetically.

Thus, we can see that in LOK and OK the word for 'cloth' must have been pəy, which coincides with EMdK pey that was prior to monophthongisation of diphthongs in the 19th century and was pronounced as [pəy], and not [pe] as in Modern Korean. Therefore, MK form pwóy with vowel wo [o] is more innovative than EMdK pey [pәy], the latter being essentially unchanged LOK and OK form.

There is also a second independent piece of evidence from dialects supporting pey rather than pwoy as an original form: Ceycwu $p e^{31}$ 'cloth' (Kim et al. 1995, p. 58), South Hamkyeng $p \varepsilon$, $p w e$, Northern Kyengsang $p i$, Southern Phyengan $p \varepsilon$ (Kim 1980, pp. 251-252). Since Ceycwu Korean and Hamkyeng Korean are in reality languages rather than dialects that split off the main cluster of Central Korean dialects before the Middle Korean texts were recorded in the 15th century, it would be puzzling if they as well as EMdK independently underwent the same innovation *poy $\rightarrow$

\footnotetext{
${ }^{29}$ The difference is only in tone, which was irrelevant for Middle Mongolian.

${ }^{30}$ Notice that 北 'north' is used as a phonetic in 背 'back'.

${ }^{31}$ Korean dialect data are given in IPA and not in Yale Romanisation.
} 
$p e \sim p \varepsilon$. Southern Hamkyeng exhibits both forms $p \varepsilon$ and $p w e$, but the latter is not an archaism supporting MK pwóy, but an innovation, resulting from a merger of South Hamkyeng /pwe/ < *poy- and /pe/ < ${ }^{*}$ pəj, ${ }^{*}{ }^{p} \wedge j-$ as /pwe/ in Hamcwu and Chengphyeng subdialects of Southern Hamkyeng, cf. MK :pwoy- [:poj-] 'to be seen' (MdK poi-) and Hamcwu/Chengphyeng pweu-, MK pòyhwó- [pیjhó-] 'to learn' (MdK pвu-) and Hamcwu/Chengphyeng pwéu- (Kim 1980, pp. 97, 443).

Thus, on the basis of typology, data from Early Middle Korean and Old Korean properly analysed, and dialect data, PK *póy 'cloth' can be reconstructed. Now this is the time for the next quote from RAM:

"With this documentation of the Korean lexical evidence in hand, and in particular in connection with the problem of the final $-r$ in Chuvash form to which Georg has now directed attention, it should be pointed out that the MK pwoy might possibly also provide a clue to the original presence of such a phoneme in its vocalic sequence -woy-... Thus an original inherited *-r- in a form something along the lines of *bori (but not *boz $<$ *bor ${ }^{2}$ !) would account for MK pwòy." (Miller 2005, p. 285)

Chuv. pir, which was exorcised from the domain of Japonic above, now appears in the domain of Korean, still longing for revenge like Hamlet's father ghost. We have already seen above that: (a) MK pwóy (not pwòy!) has HIGH and not LOW pitch; (b) it goes back to PK *pəy, thus the vowel sequence -woy- is secondary. Now, using never-failing method of reconstruction 'from above' RAM suggests that we should place a consonant $*_{-r}$ - inside that sequence on the basis of Chuv. pir. That is not all: we are also taught that initial consonant in Korean should be not *p-, but *b-

Let me deal with the problem of *-r- first. If there were MK *:pwoy with RISING pitch (indicated as : before a syllable), the reconstruction of an elided *-r(or *-1-) would be more than warranted. Cf. the following data from Middle and Old Korean:

Table 2: *-r- elision in Middle Korean

\begin{tabular}{|l|l|l|}
\hline Gloss & Middle Korean & Old Korean \\
\hline river & :nayh & 川理 NAri (SHK IV: 6) \\
\hline world & :nwuy & 世理 NWUri (SHK XIII: 8) \\
\hline lord & :nim & $\begin{array}{l}\text { ネリム, ニリ } \\
\text { nirim (Paekch) (NS XIV: 368), (NS XVI: } \\
7), \text { (NS XIX: 75), (NS XX: 109) }\end{array}$ \\
\hline old & :nyey & 舊理 NYEri (SHK XII: 1) \\
\hline Japanese & :yey & 倭理 YEri (SHK XII: 3) \\
\hline to worship & :mwoy- & 邀里 MWOri-(KHK XV: 6) \\
\hline
\end{tabular}


Thus, it is quite clear from this table that some MK (but not all) monosyllabic nouns of : $C V y$ structure with RISING pitch are likely to be derived from the OK disyllabic structure $C V r i$. If a MK noun has a LOW pitch, it is also possible that it derives from a disyllabic structure with a loss of a minimal vowel in the second syllable, as suggested in Whitman (1994, pp. 428-430) and Martin (1996, pp. 44-45). For example, kwòc 'flower' < *kwòcó, nyèk 'direction' < *nyèkú, cèk 'time' < *cèkú, wùh 'top' $<*$ wùhú, mwòk 'neck' <*mwòkó, etc. (Martin 1996, p. 45). None of monosyllabic MK nouns with LOW pitch has the shape of $C \grave{V} y$, but if MK *pwòy 'cloth' would have a LOW pitch, I could give a benefit of a doubt to its disyllabic origin. The problem, as we have seen below, that MK pwóy 'cloth' has HIGH pitch, and MK nouns with HIGH pitch seem to be predominantly, if not all, monosyllabic. This internal evidence eliminates once and for all any attempts to surgically implant Chuv. $-r$ into this Korean word. Therefore, the etymological connection between MK pwóy and Chuv. pir is based on one phoneme: initial labial stop. This is indeed an exciting practice of etymologising, previously confined to proto-Worlders, mass comparativists, and Moscow Nostraticists. But now RAM demonstrated quite well that it may be contagious.

In conclusion, I should mention that there is absolutely no evidence for reconstructing voiced *b- either for MK pwóy 'cloth' < PK * pə́y, or for any other Korean word with initial $p$-, as there are simply no phonemic initial voiced/voiceless stop contrast in any temporal or local variety of the Korean language. Thus, RAM's reconstruction *bori 'cloth' for Korean is an outstanding example of the voodoo Altaistics that RAM eloquently presented in Miller (2005) and in all his other writings over years.

$\begin{array}{ll} & \\ \text { A } & \text { High pitch initial verbal and adjectival classes } \\ \text { Chag. } & \text { Chagatay } \\ \text { Chuv. } & \text { Chuvash } \\ \text { CT } & \text { Common Turkic } \\ \text { Dag. } & \text { Daghur } \\ \text { EM } & \text { Early Mandarin } \\ \text { EMdK } & \text { Early Modern Korean } \\ \text { Eng. } & \text { English } \\ \text { EOJ } & \text { Eastern Old Japanese } \\ \text { Jur. } & \text { Jurchen } \\ \text { Kalm. } & \text { Kalmyck } \\ \text { Khal. } & \text { Khalkha } \\ \text { KVB } & \text { Kypchak Volga Bulghar } \\ \text { L } & \text { Low pitch } \\ \text { LMC } & \text { Late Middle Chinese } \\ \text { LOK } & \text { Late Old Korean } \\ \text { Ma. } & \text { Manchu } \\ \text { Mang. } & \text { Mangguer }\end{array}$




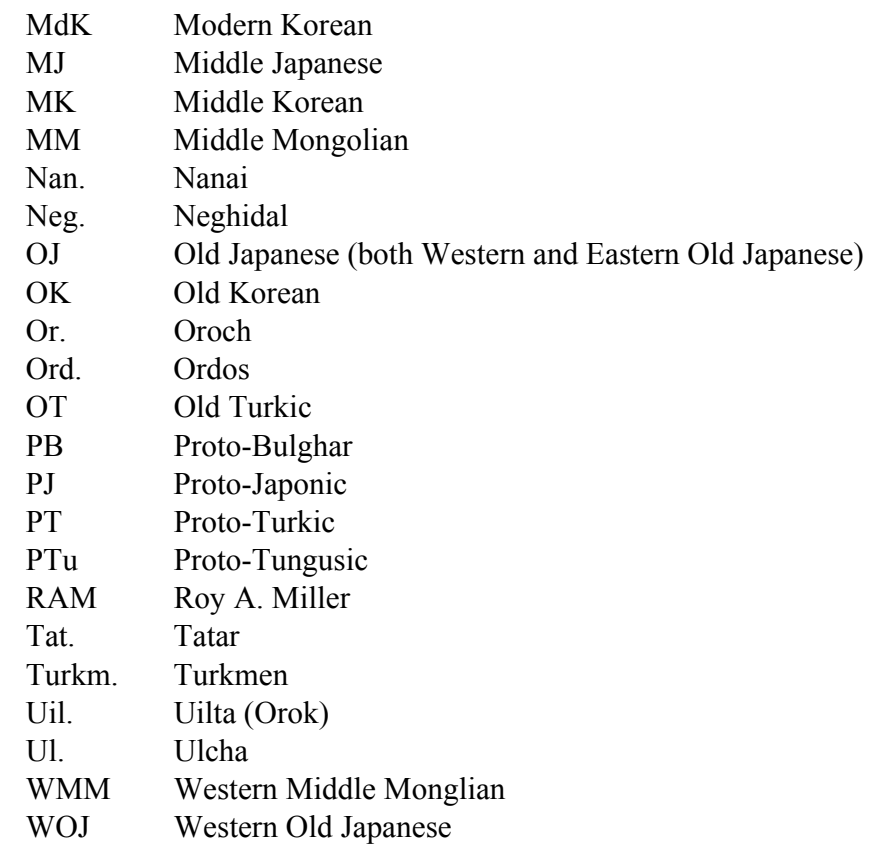

\section{Primary sources}

Japonic

KJK Kojiki, 712 AD

KK Kojiki kayō, 712 AD

MYS Man'yōshū, ca. 759 AD

NS Nihonshoki, 720 AD

Korean

HMCH Hwungmong cahoy, 1527 AD

KHK Kyunye hyangka, 1075 AD

KY Kyeylim yusa, 1103 AD

Sek Sekpo sangcel, 1449 AD

SHK Silla hyangka, 6th-8th centuries AD

YP Yongpi echenka, 1445 AD

Mongolic

HYYY Hua-yi yi-yu, 1389 AD

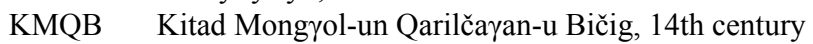

LD Leiden glossary, $1343 \mathrm{AD}$ 
MNT Mongrol niuča tobča'an, 1240 AD

MU Muqaddimat 'al-'Adab, 14th century

\section{Tungusic}

TFAXB Tongki fuqa akū xergen-i bitxe, before 1637 AD?

YK Yargiyan kooli, late 17th-early 18th century

Yong Yongningsi Jurchen inscription, 1413 AD

\section{Secondary sources}

JDB see: Omodaka (1967)

LCT see Yu Changton (1964)

\section{References}

Abdrazakov, K. S. (ed.) (1966): Tatarsko-russkii slovar'. Moscow, Sovetskaia entsiklopediia. Aiso, Teizō (1962): Kiki kayō zenchūkai. Tokyo, Yūseidō.

Andreev, I. A. - Petrov, N. P. (1971): Russko-chuvashskii slovar'. Moscow, Sovetskaia entsiklopediia.

Bentley, John R. (1997): MO and PO in Old Japanese. Unpublished MA thesis, University of Hawaii at Manoa.

Benzing, Johannes (1955): Die Tungusischen Sprachen. Wiesbaden, Verlag der Akademie der Wissenschaften und der Literatur in Mainz.

Boldyrev, Boris V. (1987): Slovoobrazovanie imen sushchestvitel'nykh v tunguso-man'chzhurskikh iazykakh. Novosibirsk, Nauka.

Cincius, Vera I. (1949): Sravnitel'naia fonetika tunguso-man'chzhurskikh iazykov. Leningrad, Uchpedgiz.

Cincius, Vera I. (ed.) (1975-1978): Sravnitel'nyi slovar' tunguso-man'chzhurskikh iazykov. Vols $1-2$. Leningrad, Nauka.

Clauson, Gerard (1972): An Etymological Dictionary of Pre-Thirteenth-Century Turkish. Oxford, Clarendon Press.

Dmitrieva, L. S. (1979): Iz etimologii nazvanii rastenii v tiurkskikh, mongol'skikh, i tunguso-man'chzhurskikh iazykakh. In: Cincius, Vera I. (ed.): Issledovaniia v oblasti etimologii altaiskikh iazykov. Leningrad, Nauka, pp. 135-191.

Doerfer, Gerhard (1985): Mongolo-Tungusica. Tungusica, B. 3. Wiesbaden, Otto Harrassowitz.

Fedotov, Mikhail R. (1996): Chuvashskii iazyk. Cheboksary, Izdatel'stvo Chuvashskogo Universiteta.

Georg, Stefan (2003): Japanese, the Altaic Theory, and the Limits of Language Classification. In: Vovin, Alexander-Osada, Toshiki (eds): Nihongo keitōron no genzai / Perspectives on the Origins of the Japanese Language. Kyoto, Nichibunken, pp. 429-449.

Haenisch, Erich (1952) Sino-Mongolische Dokumente vom Ende des 14. Jahrhunderts. Berlin, Akademie Verlag.

Haenisch, Erich (1957): Sinomongolische Glossare I. Das Hua-I ih yü. Berlin, Akademie Verlag. 
Haenisch, Erich (1962): Wörterbuch zu Manghol un Niuca Tobca'an. Wiesbaden, Franz Steiner Verlag.

Hankul hakhoy (eds) (1999): Wuli mal khun sacen. Yeys mal-kwa kul. Seoul, Emunkak.

Hattori, Shirō (1946): Genchō hishi no mōkogo wo arawasu kanji no kenkyū. Tokyo, Bunkyūdō.

Imanishi, Shunjū (1992): Mō-wa Man-wa taiyaku Manshū jitsuroku. Tokyo, Tōsui Shobō.

Ivanovskii, Aleksey O. (1894): Mandjurica I. Obrazcy solonskogo i dakhurskago iazykov. Sankt-Peterburg, Imperatorskaia Akademiia Nauk.

Jin, Guangping - Jin, Qicong (1980): Nüzhen yuyan wenzi yanjiu. Beijing, Wenwu chubanshe.

Jin, Qicong (1984): Nüzhen wen cidian. Beijing, Wenwu chubanshe.

Kane, Daniel (1989): The Sino-Jurchen Vocabulary of the Bureau of Interpreters. Bloomington, Indiana University (Uralic and Altaic Series, Vol. 153).

Kang, Sinhang (1980): Kyeylim yusa Kolye pangen yenkwu. Seoul, Sengkyunkwan tayhakkyo chwulphanpu.

Khakimzianov, Farid S. (1987): Épigraficheskie pamiatniki Volzhskoi Bulgarii i ikh iazyk. Moscow, Nauka.

Kim, Chwunghoy, et al. (1995): Hankwuk pangen calyo cip. IX kwen. Ceycwuto phyen. Sengnam, Hankwuk chengsin munhwa yenkwuwen.

Kim, Pyengcey (1980): Pangen sacen. Phyengyang, Kwahak paykkwa sacen chwulphansa.

Kiyose, Gisaburō N. (1977): A Study of the Jurchen Language and Script. Kyoto, Hōritsubunkasha.

Kiyose, Gisaburō N. (1991): Uraru sho-gengo to Nihongo: Kazaaru shi no hikaku to Miraa shi no hanron. In: Kiyose, Gisaburô Norikura: Nihon gogaku to Arutai gogaku. Tokyo, Meiji shoin, pp. 233-256.

Kurano, Kenji (1958): Kojiki (Records of Ancient Matters). Nihon Koten bungaku taikei, Vol. 1. Tokyo, Iwanami.

Kuribayashi, Hitoshi (2003): Ka-i yakugo (Kōshu-bon) mongoru go. Zen tango gobi sakuin. Sendai, Tōhoku daigaku Tōhoku Ajia kenkyū sentā.

Lewicki, Marian (1949): La langue mongole des transcriptions chinoises du XIV siècle. Le Houayi yi-yu de 1389. Wrocław, Państwowe wydawnictwo naukowe.

Lewicki, Marian (1959): La langue mongole des transcriptions chinoises du XIV siècle. Le Houayi yi-yu de 1389. Vocabulaire-index. Wrocław, Państwowe wydawnictwo naukowe.

Ligeti, Louis (1972a): Pièces de chancellerie en transcription chinoise. Budapest, Akadémiai Kiadó (Monumenta linguae Mongolicae collecta III).

Ligeti, Louis (1972b): Pièces de chancellerie en transcription chinoise. Indices verborum linguae. Budapest, Akadémiai Kiadó (Mongolicae monumentis traditorum III).

Mabuchi, Kazuo (2000): Kodai nihongo no sugata. Tokyo, Musashino shoin.

Martin, Samuel E. (1987): The Japanese Language Through Time. New Haven-London, Yale University Press.

Martin, Samuel E. (1996): Consonant Lenition in Korean and the Macro-Altaic Question. Honolulu, Center for Korean Studies.

Miller, Roy A. (1986): Linguistic Evidence and Japanese Prehistory. In: Pearson, Richard J. (ed.): Windows on the Japanese Past: Studies in Archeology and Prehistory. Ann Arbor, Center for Japanese Studies, pp. 101-120.

Miller, Roy A. (1989): Historical Pitch in Korean and Japanese. Althai Hakpo No. 1, pp. 75-141.

Miller, Roy A. (2005): Turkic böz 'fabric' in Korea and Japan. Studia Turcologica Cracoviensia No. 10, pp. 279-287.

Mostaert, Antoine (1977): Le materiel Mongol du Houa I I Iu 華夷譯語 de Houng-ou (1389), I. Bruxelles. 
Mostaert, Antoine (1995): Le materiel Mongol du Houa I I Iu 華夷譯語 de Houng-ou (1389), II Commentaires. Bruxelles.

Murofushi, Shinsuke (1979): Chūko. In: Murofushi, Shinsuke-Kobayashi, Shōjirō-Takeda, Tomohiro-Suzuki, Mayumi (eds): Nihon no koten. Tokyo, Kadokawa shoten, pp. 51-176.

Nam, Kwangwu (1997): Kyohak koe sacen. Seoul, Kyohaksa.

Ogihara, Asao-Kônosu, Hayao (eds) (1973): Kojiki. Jôdai kayô. Nihoten koten bungaku zenshû, Vol. 1. Tokyo, Shôgakukan.

Omodaka, Hisataka (ed.) (1967): Jidai betsu kokugo daijiten. Jōdai hen. Tokyo, Sanseidō.

Ōno, Susumu - Satake, Akihiro-Maeda, Kingorō (1990): Iwanami kogo jiten. Tokyo, Iwanami.

Poppe, Nikolai N. (= Nicholas) (1927-1928/1972): Das mongolische Sprachmaterial einer Leidener Handschrift. Izvestiia Akademii Nauk SSSR 1927, pp. 1009-1274; 1928, pp. 55-80. Reprinted in: Poppe, N. N.: Mongolica. Westmead, Gregg International Publishers, 1972 (pagination of the original).

Poppe, Nikolai N. (= Nicholas) (1938): Mongol'skii slovar' Mukaddimat al-Adab. Vols I-III. Moscow-Leningrad, Izdatel'stvo Akademii Nauk SSSR.

Poppe, Nicholas (1955): Introduction to Mongolian Comparative Studies. Helsinki, Suomalais-ugrilainen seura (Mémoires de la Société Finno-Ougrienne 110).

Pulleyblank, Edwin G. (1991): Lexicon of Reconstructed Pronunciation in Early Middle Chinese, Late Middle Chinese, and Early Mandarin. Vancouver, University of British Columbia Press.

Ramstedt, Gustaf J. (1949): Studies in Korean Etymology. Helsinki, Suomalais-ugrilainen seura (Mémoires de la Société Finno-Ougrienne 95).

Ramstedt, Gustaf J. (1952): Einführung in die altaische Sprachwissenschaft, II. Formenlehre. Helsinki, Suomalais-ugrilainen seura (Mémoires de la Société Finno-Ougrienne 104: 2).

Ramstedt, Gustaf J. (1957): Einführung in die altaische Sprachwissenschaft, I. Lautlehre. Helsinki, Suomalais-ugrilainen seura (Mémoires de la Société Finno-Ougrienne 104: 1).

Ramstedt, Gustaf J. (1982): Paralipomena of Korean Etymologies. Helsinki, Suomalais-ugrilainen seura (Mémoires de la Société Finno-Ougrienne 182).

Rozycki, William (1994): Mongol Elements in Manchu. Bloomington, Indiana University (Uralic and Altaic Series, Vol. 157).

Rybatzki, Volker (2003): Middle Mongol. In: Janhunen, Juha (ed.): The Mongolic Languages. London, Routledge, pp. 57-82.

Saeki, Arikiyo-Kobayashi, Yoshinori (1982): Commentary and Edition of the Second Volume of the Kojiki. In: Aoki, Kazuo-Ishimo, Dashō-Kobayashi, Yoshinori-Saeki, Arikiyo (eds): Kojiki. Nihon shisō taikei 1. Tokyo, Iwanami, pp. 116-227.

Sasse, Werner (1976): Das Glossar Koryǒ-pangǒn im Kyerim-yusa. Wiesbaden, Otto Harrassowitz.

Sergeev, Leonid P. (1968): Dialektologicheskii slovar' chuvashskogo iazyka. Cheboksary, Chuvashknigoizdat.

Sevortian, Ėrwand V. (1978): Ėtimologicheskii slovar' tiurkskikh iazykov. Vol. II: Obshchetiurkskie i mezhtiurkskie osnovy na bukvu B. Moscow, Nauka.

Skvorcov, M. I. (ed.) (1985): Chuvashsko-russkii slovar'. Moscow, Russkii iazyk.

Starostin, Sergei - Dybo, Anna-Mudrak, Oleg (2003) Etymological Dictionary of the Altaic Languages. Vols 1-3. Leiden, Brill.

Takagi, Ichinosuke - Toyama, Tamizō (1958): Kojiki taisei 7. Sōsakuin I. Tokyo, Heibonsha.

Tsuchihashi, Yutaka (ed.) (1957): Commentary and Edition of the Kojiki kayō, Nihonshoki kayō, Shoku Nihongi kayō, Fudoki kayō, and Bussoku seki no uta. In: Tsuchihashi, Yutaka-Konishi, Jin'ichi (eds): Kodai kayōshū, Nihon Koten Bungaku Taikei, Vol. 3. Tokyo, Iwanami shoten. 
Tsuchihashi, Yutaka (ed.) (1972): Kodai kayō zen chūshaku. Kojiki hen. Tokyo, Kadokawa shoten.

Vasmer, Max (1950) Etymologisches Wörterbuch der Russischen Sprache. Vol. 1. Heidelberg, C. Winter.

Vovin, Alexander (2005): A Descriptive and Comparative Grammar of Western Old Japanese. Part 1: Phonology, Script, Lexicon, and Nominals. Folkestone, Global Oriental.

Whitman, John B. (1994): The Accentuation of Nominal Stems in Proto-Korean. In: Kim-Renaud, Youngey (ed.): Theoretical Issues in Korean Linguistics. Chicago, Center for the Study of Language and Information, pp. 425-439.

Yu, Changton (1964): Yi co e sacen. Seoul, Yensey tayhakkyo chwulphanpu. 